SMU Law Review Forum

Volume 73

Article 21

$11-2020$

\title{
When "One Step" Is a Leap: Examining the Fifth Circuit's Correct Interpretation of the Federal Sentencing Guidelines
}

Brooke Vaydik

Southern Methodist University, Dedman School of Law

\section{Recommended Citation}

Brooke Vaydik, When "One Step" Is a Leap: Examining the Fifth Circuit's Correct Interpretation of the Federal Sentencing Guidelines, 73 SMU L. REV. F. (2020)

https://doi.org/10.25172/slrf.73.1.21

This Case Note is brought to you for free and open access by the Law Journals at SMU Scholar. It has been accepted for inclusion in SMU Law Review Forum by an authorized administrator of SMU Scholar. For more information, please visit http://digitalrepository.smu.edu. 


\title{
SMU Law Review Forum
}

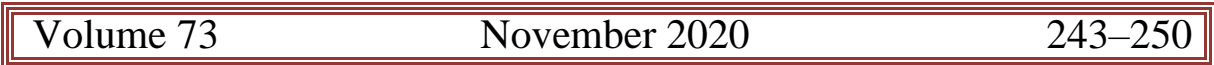

\section{WHEN “ONE STEP” IS A LEAP: EXAMINING THE FIFTH CIRCUIT'S CORRECT INTERPRETATION OF THE FEDERAL SENTENCING GUIDELINES}

\author{
Brooke Vaydik
}

\section{INTRODUCTION}

In United States v. Eaden, the United States Court of Appeals for the Fifth Circuit interpreted an application note of the Federal Sentencing Guidelines (the Guidelines) narrowly, holding that the presence of ammunition without a gun during a drug arrest should not enhance a federal defendant's sentence. ${ }^{1}$ The court interpreted a Guideline that enhanced a sentence "if the defendant ... used or possessed any firearm or ammunition in connection with another felony offense." ${ }^{2}$ The application note to the Guideline clarified that a presumption exists that a firearm is used in connection with an offense when the "firearm is found in close proximity to drugs," but does not mention ammunition at all. ${ }^{3}$ Because the defendant possessed ammunition without a gun, the court had to determine whether the Guideline presumed a connection with an offense when only ammunition is present. ${ }^{4}$ The Fifth Circuit held that ammunition alone was not enough to give rise to such a presumption ${ }^{5}$ and split with a prior holding from the Sixth Circuit, where the court held that the presence of ammunition alone brought a criminal "one step closer" to having a gun and thus gave rise to a presumption that weapons were being used in furtherance of the crime. ${ }^{6}$ This Case Note examines the Fifth Circuit's correct holding against the background of

* J.D. Candidate, SMU Dedman School of Law, 2021; B.A., Boston University, 2011. Thank you to my father and mother, Greg and Tammy Vaydik, and my sister, Bryn Vaydik, for all of their love and support.

1. United States v. Eaden, 914 F.3d 1004, 1008 (5th Cir. 2019).

2. U.S. SENT'G GUIDELINES MANUAL $\S 2$ K2.1(b)(6)(B) (U.S. SENT'G COMM’N 2018).

3. Id. § $2 \mathrm{~K} 2.1 \mathrm{cmt} .14(\mathrm{~B})$.

4. Eaden, 914 F.3d at 1007.

5. Id. at 1010 .

6. United States v. Coleman, 627 F.3d 205, 213 (6th Cir. 2010). 
the development of the Guidelines and discusses the importance of interpreting the Guidelines narrowly in light of the outcomes of sentencing reform.

\section{LEGAL BACKGROUND}

In 1984, Congress passed the Sentencing Reform Act (SRA), a comprehensive legislative overhaul of the determination of sentencing for federal crimes. ${ }^{7}$ In addition to controlling crime, ${ }^{8}$ Congress's goal in passing the SRA was the "elimination of disparity [in federal sentences] through adoption of a uniform sentencing philosophy." "Before the SRA was passed, federal sentencing was greatly disparate, with defendants sometimes receiving vastly different sentences for the same crime, often along racial and economic lines. ${ }^{10}$ As a response, the SRA created the Federal Sentencing Commission (the Commission), an independent agency within the judicial branch made up of seven appointed members, at least three of which were required to be federal judges. ${ }^{11}$ The Commission would be responsible for the drafting and establishment of uniform sentencing policies for the federal system, including "determinate sentencing guidelines." ${ }^{2}$

The Commission promulgated the first Guidelines in 1987, noting that they were "but the first step in an evolutionary process" and "a practical effort toward the achievement of a more honest, uniform, equitable, and therefore effective, sentencing system." ${ }^{13}$ In order to constrain the judicial discretion that had led to "unwarranted disparity in the pre-Guidelines era," the Guidelines developed by the Commission were binding upon federal judges when determining a defendant's sentence. ${ }^{14}$ In Mistretta v. United States, the United States Supreme Court affirmed the constitutionality of the Commission, holding that Congress did not abuse its delegation powers by establishing the Commission and charging it with creating the Guidelines because Congress was specific and narrowly tailored in its delegation. ${ }^{15}$ In a scathing and famous dissent, Justice Antonin Scalia argued that there was "no place within [the] constitutional system" for an agency other than Congress to create legally binding rules. ${ }^{16}$ Nevertheless, the Court's ruling in Mistretta allowed the Commission to continue to promulgate binding Sentencing Guidelines until the Supreme Court addressed the constitutionality of the Guidelines themselves in United States v. Booker over

7. Paul J. Hofer \& Mark H. Allenbaugh, The Reason Behind the Rules: Finding and Using the Philosophy of the Federal Sentencing Guidelines, 40 AM. CRIM. L. REV. 19, 20 (2003).

8. See Jeffrey S. Parker \& Michael K. Block, The Limits of Federal Criminal Sentencing Policy; Or, Confessions of Two Reformed Reformers, 9 GEO. MASON L. REV. 1001, 1006 (2001).

9. Hofer \& Allenbaugh, supra note 7, at 25.

10. See David E. Patton, Guns, Crime Control, and a Systemic Approach to Federal Sentencing, 32 CARDOZO L. REV. 1427, 1465-66 (2011).

11. Hofer \& Allenbaugh, supra note 7, at 20 n.4.

12. Parker \& Block, supra note 8 , at 1011.

13. U.S. SENT'G GUIDELINES MANUAL ch. 1 (U.S. SENT'G COMM'N 1987).

14. Hofer \& Allenbaugh, supra note 7, at 22-23.

15. Mistretta v. United States, 488 U.S. 361, 374 (1989).

16. Id. at 413 (Scalia, J., dissenting). 
twenty-five years later. ${ }^{17}$

By the time Booker was decided in 2005, the nation was already feeling the impact of the SRA and the mandatory Guidelines. Between 1980 and 2010, the federal prison population in the United States had increased at a rate of $222 \%$, which the National Research Council attributed "entirely to changes in sentencing policy." ${ }^{18}$ Several federal judges resigned from the bench in protest of the harsh and inflexible nature of the Guidelines, with one judge saying he "just [couldn't], in good conscience, continue to do this." ${ }^{19}$ Further, the Commission ignored Congress's suggestion "that nonviolent, first-time offenders ... ordinarily receive non-prison sentences." ${ }^{20}$ This policy choice reduced the percentage of offenders sentenced to probation to just $7.1 \%$, a decline from $37 \%$ in $1985 .^{2}$

For the first time in its post-SRA jurisprudence, the Supreme Court held in Booker that the Guidelines' consistent application of sentences above the statutory maximums without the factual findings of a jury violated defendants' right to a jury trial as enshrined in the Sixth Amendment. ${ }^{22}$ Additionally, the Court found that, while the provision of the SRA that made the Guidelines mandatory was unconstitutional, it was not appropriate to strike down the entire Act. ${ }^{23}$ As a result, the Court held that the Guidelines would now be advisory for federal judges-"requir[ing] a sentencing court to consider Guidelines ranges, but . . . permit[ting] the court to tailor the sentence in light of other statutory concerns as well." ${ }^{24}$ This shift from binding law to a guideline in the truest sense of the word made the Guidelines and recommendations of the Commission truly voluntary. However, studies that have tracked the use of the Guidelines in sentencing since the Booker decision have shown that more often than not, federal judges stick closely to the ranges recommended by the Guidelines. ${ }^{25}$

\section{FACTUAL BACKGROUND}

It was against this tension that the interpretation issue arose in Eaden. Police officers properly obtained and executed a search warrant on Eaden's home after previously making an undercover purchase of a substance they identified to be crack cocaine. ${ }^{26}$ In addition to finding 5.5 grams of crack cocaine inside the home, officers found nineteen rounds of ammunition that were "easily accessible and stored in close proximity to" the drugs. ${ }^{27}$ However, despite finding ammunition,

17. See United States v. Booker, 543 U.S. 220, 226 (2005).

18. Marc Mauer, Long-Term Sentences: Time to Reconsider the Scale of Punishment, 87 UMKC L. REV. 113, 113, 120 (2018).

19. Michelle Alexander, The New Jim Crow: Mass Incarceration in the Age of COLORBLINDNESS 92 (rev. ed. 2012).

20. Mauer, supra note 18 , at 121.

21. Id.

22. Booker, 543 U.S. at 244.

23. Id. at 248-49.

24. Id. at 245 (citations omitted).

25. Patrick Schepens, Note, Solomon's Choice: Severing the Mandatory Requirement of the Federal Sentencing Guidelines to Save a System Congress Never Intended, 26 MISS. C.L. REV. 375, 420 (2007).

26. United States v. Eaden, 914 F.3d 1004, 1006 (5th Cir. 2019).

27. Id. 
no gun was found on Eaden or anywhere else in the home, and there was no other indication that the ammunition was in any way connected to the drugs. ${ }^{28}$ Eaden claimed that he had found the ammunition in a dumpster and brought it home, and the court noted that "[t]he record ... [did] not indicate that the ammunition was in plain sight during the controlled purchase." ${ }^{29}$ Because Eaden had been previously convicted for a state drug felony offense, he "was charged in federal court with possession of ammunition as a felon," to which he pleaded guilty. ${ }^{30}$

Under the Federal Rules of Criminal Procedure, a probation officer "must conduct a presentence investigation and submit a report to the court before it imposes sentence." ${ }^{31}$ This Presentence Report (PSR) is required to "calculate the defendant's offense level and criminal history category" and is also required to "identify all applicable guidelines and policy statements of the Sentencing Commission." " Eaden's PSR identified "a base offense level of fourteen" as a result of his prior felony conviction and a four-level enhancement due to his possession of ammunition "in connection with another felony offense." ${ }^{33}$ The PSR calculated this enhancement based off of the Guidelines, which recommend a four-level enhancement "if the defendant ... used or possessed any firearm or ammunition in connection with another felony offense." 34

During the course of the statutorily-mandated objection period, ${ }^{35}$ Eaden objected to the report's recommendation of the firearm enhancement, arguing that his possession of ammunition alone without the presence of a firearm could not, for the purposes of the PSR, be construed to have facilitated his drug trafficking offense. ${ }^{36}$ The PSR recommended a four-level sentencing enhancement despite Eaden's objections, noting the lack of Fifth Circuit precedent, the plain text of the Guideline's "application note," and a relatively recent decision in the Sixth Circuit that upheld an enhancement in a similar situation when ammunition, but not a firearm, was present. ${ }^{37}$ In United States v. Coleman, the Sixth Circuit found that ammunition alone was enough to trigger the sentencing enhancement through the "fortress theory," which states that "a connection [between the firearm and the crime] is established if it reasonably appears that the firearms found on the premises controlled or owned by a defendant ... are to be used to protect the drugs or otherwise facilitate a drug transaction." "In applying this "fortress theory," the PSR in Eaden's case stated that "because the ammunition "potentially emboldened Eaden in the knowledge that he was one step closer to having a fully-loaded firearm to protect ... his illegal drugs, .... the

28. Id.

29. Id.

30. Id.

31. FED. R. CRIM. P. 32(c)(1)(A).

32. Id. 32(d)(1)(A)-(B).

33. Eaden, 914 F.3d at 1006

34. U.S. SENT'G GUidelines MANUAL § 2K2.1(b)(6)(B) (U.S. SENT'G COMM'N 2018).

35. FED. R. CRIM. P. 32(f)(1).

36. Eaden, 914 F.3d at 1006

37. Id.; United States v. Coleman, 627 F.3d 205, 214 (2010).

38. Coleman, 627 F.3d at 212 (quoting United States v. Richardson, 510 F.3d 622, 626 (6th Cir. 2007)). 
possession alone was connected with the drug trafficking offense. ${ }^{39}$ Over Eaden's objections at the subsequent sentencing hearing, the judge accepted the PSR's recommendation of the four-level sentencing enhancement, finding that the evidence showed that his "possession of the ammunition facilitated or had the potential to facilitate his drug trafficking crime offense." ${ }^{40}$ It was this application of the Guidelines, specifically § 2K2.1(b)(6)(B), that Eaden appealed to the Fifth Circuit. $^{41}$

On appeal, the Fifth Circuit considered two related questions, both issues of first impression, that would determine whether Eaden's possession of ammunition by itself was enough to trigger a four-level sentencing enhancement under the Guidelines. ${ }^{42}$ First, the court determined that ammunition alone could sometimes facilitate drug trafficking for purposes of the enhancement under the Guidelines, but only "under appropriate circumstances not present in this case." 43 Analyzing the plain text of the Guideline itself, which states that the enhancement applies "if the defendant... used or possessed any firearm or ammunition in connection with another felony offense," ${ }^{44}$ the court determined that the use of the word "or" plainly indicated that the Commission contemplated that there would be instances when ammunition alone would be enough to apply the enhancement. $^{45}$

The second question the court had to answer, however, was more fact-intensive and specific: "whether, as is true with a firearm, there is a presumption of facilitation when ammunition alone is present at the time of the drug trafficking offense." ${ }^{46}$ Although the text of the Guideline clearly states that ammunition alone can sometimes facilitate a drug trafficking offense, the Fifth Circuit noted that this falls short of an outright presumption and chose to consult the Guideline's application note for further clarification. ${ }^{47}$ The application notes to the Guidelines "generally bind federal courts unless they are inconsistent with the text of the Guideline." 48 Thus, a court's interpretation of a Guideline's application note has the same bearing on a defendant's sentence as a court's interpretation of the Guideline itself. The application note that applied to the section at issue in this case, however, very clearly did not mention ammunition at all. ${ }^{49}$ The note only contemplates a situation in which a "firearm is found in close proximity to drugs"; ${ }^{50}$ only then can the facilitation of a drug offense be presumed.

\footnotetext{
39. Eaden, 914 F.3d at 1006.

40. Id. at 1007 .

41. Id. at 1005

42. Id. at 1007 .

43. Id.

44. U.S. Sent'G Guidelines MANuAL § 2K2.1(b)(6)(B) (U.S. Sent'G COMm'N 2018) (emphasis added).

45. Eaden, 914 F.3d at 1008

46. Id.

47. Id.

48. United States v. Ochoa-Gomez, 777 F.3d 278, 282 (5th Cir. 2015) (citing United States v. Garcia-Rodriguez, 415 F.3d 452, 455 (5th Cir. 2005); United States v. Ho, 311 F.3d 589, 610 (5th

49. Eaden, 914 F.3d at 1008 (citing § 2 K2.1 cmt. n.14(B)).

50. § $2 \mathrm{~K} 2.1 \mathrm{cmt} . \mathrm{n} .14(\mathrm{~B})$.
} Cir. 2002)). 
The court found that, because the application note was "addressed specifically to the drug trafficking context" and only mentioned firearms without reference to ammunition alone, a presumption of facilitation could not be extended to a situation like Eaden's. ${ }^{51}$ Because there was no presumption, the court held that the government was obligated to affirmatively show that "the possession of ammunition facilitated or had the potential to facilitate the other offense." showing could be made by proving that the ammunition was in plain sight or was brandished during the commission of the underlying drug trafficking felony. ${ }^{53}$ Applying this to the facts of the case, the court found that there was no evidence that the ammunition was in plain sight; in fact, the underlying record indicated that the ammunition was merely "stored in close proximity to the illegal drugs." 54 As a result, the court held that the four-level sentence enhancement recommended by the PSR and applied by the district court judge was improper and remanded the case for resentencing. ${ }^{55}$

In finding the enhancement to be improper, the court noted its split with the Sixth Circuit's decision in Coleman, where the Sixth Circuit found that the presumption of facilitation was proper when ammunition alone was present at the scene of a drug crime. ${ }^{56}$ Using traditional canons of construction, the Sixth Circuit first interpreted the plain meaning of the Guideline and its application note and found that by using the word "facilitate," which means " to make easier or less difficult," the Guideline encompassed a situation in which ammunition alone was present at the scene of a drug crime. ${ }^{57}$ The court reasoned that storing the ammunition in close proximity to the drugs "reduced or had the potential to reduce the difficulty of completing the felony drug trafficking." ${ }^{58}$ The court rejected the defendant's argument that the presence of ammunition alone did not increase the likelihood of violence during a drug transaction, stating that even getting "one step closer to having a loaded firearm" was enough to trigger the presumption in the application note. ${ }^{59}$

\section{ANALYSIS}

The Fifth Circuit took the correct approach in splitting with prior circuit court precedent and rejecting the sentencing enhancement for Eaden. By applying the enhancement narrowly, the court stayed true to the original intent of the Guideline-to punish crimes of violence in connection with drug trafficking ${ }^{60}-$

51. Eaden, 914 F.3d at 1008

52. Id. at 1009 (citing United States v. Jeffries, 587 F.3d 690, 692, 694-95, 694 n.9 (5th Cir. 2009)).

53. Id.

54. Id. at 1010 .

55. Id.

56. Id.; United States v. Coleman, 627 F.3d 205, 213 (6th Cir. 2010).

57. Coleman, 627 F.3d at 212.

58. Id.

59. Id. at 213 .

60. See, e.g., United States v. McDonald, 165 F.3d 1032, 1037 (6th Cir. 1999) ("[Section $2 \mathrm{~K} 2.1(\mathrm{~b})]$ is a sentencing enhancement provision that was created in response to a concern about the increased risk of violence when firearms are used or possessed during the commission of another 
while ensuring that an arbitrary application of a significant sentencing enhancement did not further contribute to the epidemic of mass incarceration in this country. First, the court correctly held that the plain language of the Guideline, coupled with its application note, precluded a finding that Eaden's possession of ammunition alone facilitated his drug trafficking offense. ${ }^{61}$ While the Guideline itself does mention ammunition, the application note clarifies when a presumption can be broadly applied and only mentions firearms. ${ }^{62}$ Without more clarity, it would be irresponsible to extend the presumption, as the Sixth Circuit did, to all instances in which ammunition is found without a firearm. This extension would subject defendants to increasingly harsher punishments for the sole reason that, in the words of the Sixth Circuit, they were "one step closer" to having a gun. ${ }^{63}$ "One step closer," however, should not be enough to deprive someone of their liberty-it is impossible to know, without further fact-finding, whether someone will continue to take the remaining steps.

Second, the Fifth Circuit's holding in Eaden was correct because applying a blanket presumption of facilitation to drug trafficking crimes where only ammunition is found would lead to absurd results that could not possibly have been contemplated by the drafters of the Guidelines. While the Fifth Circuit did note that in some circumstances ammunition can facilitate a crime, it was correct in concluding that a presumption would go too far. ${ }^{64}$ If a presumption were to be applied, possessing even one bullet would be enough to trigger the sentencing enhancement under the language of the Guidelines. This is clearly contrary to the intent of the enhancement-to punish violence in connection with drug crimes. ${ }^{65}$ As the dissent in Coleman correctly noted, the "possession of nothing but bullets" and even the display of bullets does not cause immediate harm. ${ }^{66}$ A person needs something more-indeed, they must go "one step" further-for the ammunition to make a difference in the commission of a crime. And as the Fifth Circuit correctly noted, that is a determination that must be made on a case-by-case basis, not as a blanket presumption. ${ }^{67}$

Finally, any interpretation of the Guidelines must be looked at through the lens of our country's current mass incarceration epidemic. As noted previously, the strict nature of the Guidelines, and the frequency with which they are applied by federal judges, has led to an increase in the U.S. prison population and the length of the average federal prison sentence. ${ }^{68}$ As the conversation around sentencing reform increasingly leads to action at the federal level, ${ }^{69}$ it is important

felony.").

61. See Eaden, 914 F.3d at 1010.

62. See U.S. Sent'G Guidelines MANuAl § 2K2.1(b)(6)(B) (U.S. Sent'G COMM'N 2018).

63. Coleman, 627 F.3d at 213.

64. See Eaden, 914 F.3d at 1007-08.

65. See, e.g., McDonald, 165 F.3d at 1037.

66. Coleman, 627 F.3d at 216 (Gilman, J., dissenting).

67. Eaden, 914 F.3d at 1008.

68. Shon Hopwood, The Effort to Reform the Federal Criminal Justice System, 128 YALE L.J.F. 791, 793 (2019).

69. See, e.g., Nicholas Fandos, Senate Passes Bipartisan Criminal Justice Bill, N.Y. TIMES (Dec. 18, 2018), https://www.nytimes.com/2018/12/18/us/politics/senate-criminal-justice-bill.html [https://perma.cc/7SWY-9A6N]. 
that federal judges at the front lines of sentencing avoid contributing to the problem by narrowly interpreting the Guidelines where possible and applying them only where the situation warrants. In Eaden's case, the four-level sentencing enhancement would have almost doubled his original sentence solely because he possessed something which had the vague potential to cause harm-but only if he acquired an actual firearm.

While the concerns addressed by the Guidelines are important, it is equally important to ensure that the Guidelines are applied fairly and not arbitrarily in the face of ambiguity. By construing the Guideline narrowly and staying true to the plain language of the Guideline and its application note, the Fifth Circuit avoided handing down an inequitable and unfair punishment that would only contribute to the overly long prison sentences that federal inmates often receive. Other courts confronting this question should follow this example and ensure that defendants are punished for crimes they actually do commit-not for coming "one step closer" to a crime they might commit. 